\title{
What can nuclear microsatellites tell us about maritime pine genetic resources conservation and provenance certification strategies?
}

\author{
Jérémy Derory ${ }^{a}$, Stéphanie Mariette ${ }^{\mathrm{a}, \mathrm{b}}$, Santiago C. Gonzaléz-Martínez ${ }^{\mathrm{c}}$, David Chagnéa, \\ Delphine Madur ${ }^{\mathrm{a}}$, Sophie Gerber ${ }^{\mathrm{a}}$, Jean Brach ${ }^{\mathrm{a}}$, François Persyn ${ }^{\mathrm{d}}$, Maria M. Ribeiro ${ }^{\mathrm{e}}$ \\ and Christophe Plomion ${ }^{\mathrm{a}^{*}}$ \\ a INRA, Équipe de Génétique et Amélioration des Arbres Forestiers, 69 route d'Arcachon, 33612 Cestas Cedex, France \\ ${ }^{\mathrm{b}}$ Cemagref, Domaine des Barres, 45290 Nogent-sur-Vernisson, France \\ ${ }^{\mathrm{c}}$ CIFOR-INIA, Department of Breeding and Biotechnology, P.O. Box 8111, 28080 Madrid, Spain \\ ${ }^{\mathrm{d}}$ Services Espaces Verts, 62520 Le Touquet, France \\ ${ }^{e}$ Escola Superior Agrária, Dep de Silvicultura e Recursos Naturais, Quinta da Senhora de Mércules, Apdo 119, 6001-909 Castelo Branco, Portugal
}

(Received 16 August 2001; accepted 13 March 2002)

\begin{abstract}
Maritime pine (Pinus pinaster Ait.) is the first conifer used for reforestation in France and now covers 2.4 million ha of the Iberian Peninsula. In order to preserve the genetic resources of this economically and ecologically important species prior knowledge of the distribution of genetic diversity is needed. In this paper, a genetic diversity study was performed using nuclear simple sequence repeats (SSRs or microsatellites). Classical parameters of diversity (allelic richness and heterozygosity) and differentiation were estimated for 47 populations of $P$. pinaster. Most of the populations (40) were collected in France, six populations were also collected in the Iberian Peninsula and one Moroccan population was also included in the study. The population genetic parameters indicated that some populations should be a focus of conservation efforts (higher level of diversity, higher allelic richness and presence of rare alleles). A diagnostic test for sample origin was developed to distinguish Corsican from Landes populations.
\end{abstract}

Pinus pinaster / nuclear microsatellites / genetic diversity / conservation / provenance identification

Résumé - Que nous indiquent les microsatellites nucléaires sur la conservation des ressources génétiques du pin maritime et sur les stratégies de certification de provenances ? Le pin maritime (Pinus pinaster Ait.) est le premier conifère utilisé pour le reboisement en France et couvre environ 2,4 millions d'hectares dans la péninsule Ibérique. Dans le but de conserver les ressources génétiques de cette espèce, importante du point de vue économique et écologique, une connaissance préalable de la distribution de sa diversité génétique est nécessaire. Dans ce papier, une étude de diversité génétique a été menée en utilisant des marqueurs microsatellites. Les paramètres classiques de diversité (richesse allélique et hétérozygotie) et de différenciation ont été calculés au sein de 47 populations. La plupart des populations (40) ont été échantillonnées en France, six populations ont été choisies dans la Péninsule Ibérique et une population marocaine a également été incluse dans l'analyse. Les résultats de génétique des populations montrent que certaines populations pourraient être intéressantes pour la conservation des ressources génétiques de l'espèce (niveau d'hétérozygotie ou de richesse allélique plus élevée que les autres populations, présence d'allèles rares). Nous avons montré que les résultats de cette analyse fournissent un test diagnostic pour distinguer les populations d'origine landaise des populations d'origine corse.

Pinus pinaster / microsatellites nucléaires / diversité génétique / conservation / certification de provenance

\section{INTRODUCTION}

Pinus pinaster Ait. occurs naturally in southwestern Europe (France, Portugal, Spain and Italy) and northwestern Af- rica (Algeria, Tunisia and Morocco) (Farjon, [9]). Its distribution is discontinuous due to geographic isolation of populations and to the ancient human impact in the Mediterranean Basin. The rangewide genetic diversity of maritime pine is of

* Correspondence and reprints

Tel.: +33557 1228 38; fax: +33557 1228 81; e-mail: plomion@pierroton.inra.fr 
interest for ecologic and economic reasons. In a large part due to its economic importance as a plantation species, genetic resources of $P$. pinaster are now threatened. In France, 15000 ha of improved seedlings are planted each year in the south-west and the introduction of improved material may modify the distribution of genetic diversity of the species. Secondly, the introduction of seeds from other geographical regions may alter the local genetic structure of the species and may constitute populations that are not adapted to the local environment, as occurred when Portuguese seeds were introduced in the south-west of France (Boisseaux [5]). In areas such as the Iberian Peninsula, stands of $P$. pinaster are under a strong human impact through recurrent forest fires and reforestation with seedlings of unknown origin (Ribeiro et al. [21]). Southeastern and Corsican populations are affected by the spread of the bast scale Matsucoccus feytaudi Duc (Jactel et al. [14]; Jactel et al. [15]). Also, mediterranean populations typically display low effective population sizes in contrast with "atlantic" populations (Landes, Portugal, Galicia); such that loss of genetic diversity may be more prevalent in these populations.

To preserve the genetic diversity of $P$. pinaster, a conservation strategy is being planned and identification tests are to be developed to detect allochtonous seed flow in populations. Prior knowledge of the geographical distribution of genetic diversity level is needed for this purpose.

The genetic and phenotypic variation of $P$. pinaster has been studied using various methods. Intraspecific phenotypic variation of $P$. pinaster has been investigated in numerous provenance trials established in different countries (Alía et al. [1]; Alía et al. [2]; Harfouche and Kremer [13]). Those field experiments have shown that morphological and adaptative traits vary significantly among provenances and, generally, a significant genotype-environment interaction is observed (Alía et al. [2]). Several range-wide genetic diversity surveys have been carried out using terpenes, isozymes, denaturated proteins and chloroplast microsatellites (Baradat and Marpeau-Bezard [4]; Bahrman et al. [3]; Petit et al. [19]; Vendramin et al. [25]). Recent studies have been undertaken at a regional level using isozymes, AFLP markers (Amplified Fragment Length Polymorphisms), nuclear and chloroplast microsatellite markers (Salvador et al. [24]; González-Martínez et al. [11]; Mariette et al. [18]; Ribeiro et al. [21]). A test based on chloroplast microsatellites has very recently been developed in order to determine the putative origin of $P$. pinaster stands in the Aquitaine region of France (Ribeiro et al. [22]). This test gives faster and more accurate results than the previous terpene-based test developed by Baradat and Marpeau-Bezard [4].

In this paper, forty-seven populations of $P$. pinaster (forty from France, four from Spain, two from Portugal and one from Morocco) were analysed with three nuclear simple sequence repeats (SSRs or microsatellites). This marker type was used in preference to isozymes or dominant markers as its high rate of polymorphism is particularly useful for detec- tion of allelic richness within populations. The main objective of this study was to synthetize patterns found for nuclear SSRs with previously published results (Mariette et al. [18]). We discus the effectiveness of microsatellites to define conservation strategies in the species and described a test for seed origin identification developed from nuclear SSR data.

\section{MATERIALS AND METHODS}

\subsection{Plant material and DNA analysis}

Forty-seven populations of $P$. pinaster were used in the present study; their name and location are listed in table I. Their location in the natural range of $P$. pinaster is given in figure 1. From each population, 30 individuals were sampled. Sixteen populations from France sampled in the west, in the centre and in the south-east were studied. In addition, data from $23 P$. pinaster populations from France for the same SSR loci [thirteen from the south-west of France (Aquitaine) and ten from Corsica] analysed in a previous study were included (Mariette et al. [18]). A putative Corsican population (Devinas), introduced in the Aquitaine region 35 years ago, was also analysed. Finally, four populations from Spain (Coca, Cómpeta, Boniches and Cazorla), two from Portugal (Oleiros and Leiria) and one from Morocco were used.

The DNA was extracted from needles according to the Doyle and Doyle [7] protocol and amplification of nuclear microsatellites was performed as described by Mariette et al. [17]. Three SSRs (coded FRPP91, FRPP94 and ITPH4516) were used.

\subsection{Genetic diversity statistical analysis}

Principal component analysis (PCA) was used to retrieve information about the clustering pattern of the analysed populations. PCA was performed based on the allele frequencies of the seven most frequent alleles, for each microsatellite.

For each locus, the allelic richness (number of alleles, $A$ ), the allelic frequencies, the observed heterozygosity $\left(H_{\mathrm{O}}\right)$, the expected heterozygosity $\left(H_{\mathrm{E}}\right)$, and the fixation index $\left[F_{\mathrm{IS}}=1-\left(H_{\mathrm{O}} / H_{\mathrm{E}}\right)\right]$ were calculated as described by Brown and Weir [6]. These parameters were estimated per population and for each geographical group of populations detected with the PCA (West of France, South-East of France, Iberian Peninsula), separately. The means over the three loci were calculated.

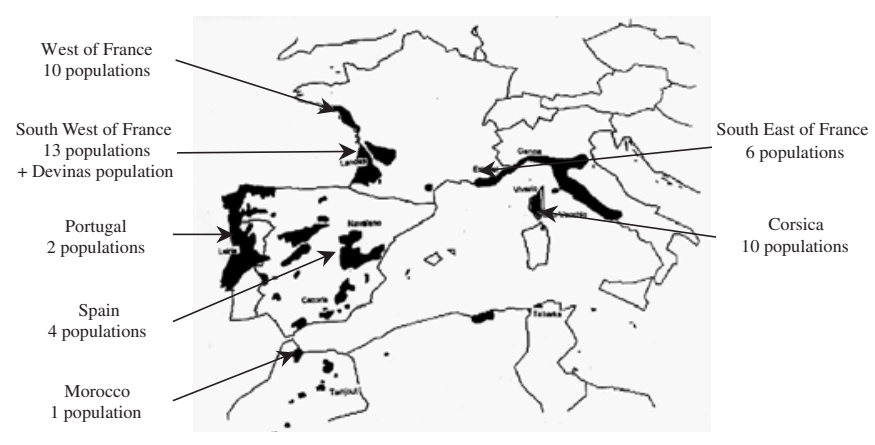

Figure 1. Location of studied populations of $P$. pinaster. 
Table I. List of the studied P. pinaster populations.

\begin{tabular}{|c|c|c|c|}
\hline $\begin{array}{l}\text { Data file } \\
\text { number }\end{array}$ & Population Id & Population name & Location \\
\hline 1 & $\mathrm{Aq} 1$ & Lit-et-Mixe & Aquitaine (France) \\
\hline 2 & $\mathrm{Aq} 2$ & St-Julien-en-Born & Aquitaine (France) \\
\hline 3 & $\mathrm{Aq} 3$ & Boulevard des Allemands & Aquitaine (France) \\
\hline 4 & $\mathrm{Aq} 4$ & Ste-Eulalie-en-Born & Aquitaine (France) \\
\hline 5 & Aq5 & Mimizan & Aquitaine (France) \\
\hline 6 & Aq6 & Vielle-St-Girons & Aquitaine (France) \\
\hline 7 & Aq7 & Domaniale de Biscarosse & Aquitaine (France) \\
\hline 8 & Aq8 & Usagère de Biscarosse & Aquitaine (France) \\
\hline 9 & Aq9 & Lège & Aquitaine (France) \\
\hline 10 & Aq10 & Lacanau & Aquitaine (France) \\
\hline 11 & Aq11 & Pointe de Grave & Aquitaine (France) \\
\hline 12 & Aq12 & Carcans & Aquitaine (France) \\
\hline 13 & Aq13 & Hourtin & Aquitaine (France) \\
\hline 14 & Col & Pineto & Corse (France) \\
\hline 15 & $\mathrm{Co} 2$ & Restonica & Corse (France) \\
\hline 16 & $\mathrm{Co} 3$ & Ominanda & Corse (France) \\
\hline 17 & $\mathrm{Co} 4$ & Tova & Corse (France) \\
\hline 18 & Co5 & Cagna & Corse (France) \\
\hline 19 & Co6 & Aullene & Corse (France) \\
\hline 20 & $\mathrm{Co} 7$ & Pinia & Corse (France) \\
\hline 21 & $\operatorname{Co} 8$ & Bonifatu & Corse (France) \\
\hline 22 & $\mathrm{Co} 9$ & Vero & Corse (France) \\
\hline 23 & Co10 & Ventilegne & Corse (France) \\
\hline 24 & Devinas & Devinas & Corse in Landes \\
\hline 25 & Go1 & St Trojan & West of France \\
\hline 26 & Go2 & Olonne & West of France \\
\hline 27 & Go3 & St Jean & West of France \\
\hline 28 & Go4 & Erdeven & West of France \\
\hline 29 & Go5 & Pleucadec & West of France \\
\hline 30 & Go6 & Brain & West of France \\
\hline 31 & Go7 & Pompogne & West of France \\
\hline 32 & Go8 & Vieille Brioude & West of France \\
\hline 33 & Go9 & Aubazines & West of France \\
\hline 34 & Go10 & Le Touquet & West of France \\
\hline 35 & Se1 & Maures & South East of France \\
\hline 36 & $\mathrm{Se} 2$ & Alpes Maritimes & South East of France \\
\hline 37 & $\mathrm{Se} 3$ & Var & South East of France \\
\hline 38 & $\mathrm{Se} 4$ & Esterel & South East of France \\
\hline 39 & $\mathrm{Se} 5$ & Gard & South East of France \\
\hline 40 & Se6 & Corbières & South East of France \\
\hline 41 & Sp1 & Coca & Spain \\
\hline 42 & $\mathrm{Sp} 2$ & Cómpeta & Spain \\
\hline 43 & $\mathrm{Sp} 3$ & Boniches & Spain \\
\hline 44 & Sp4 & Cazorla & Spain \\
\hline 45 & Po1 & Oleiros & Portugal \\
\hline 46 & Po2 & Leiria & Portugal \\
\hline 47 & Mor & Morocco & Morocco \\
\hline
\end{tabular}

Values of genetic differentiation, $F_{\mathrm{ST}}$, were estimated following Weir and Cockerham [26]. However, as microsatellites can be assumed to evolve following a Stepwise Mutation Model, $\rho_{\mathrm{ST}}$ values were also estimated following Rousset [23]. These parameters were calculated among all populations within each geographical group and among all the populations. The significance of the differentiation between pairs of populations was tested following Raymond and Rousset [20].

\subsection{Test for provenance identification}

Mariette et al. [18] showed that, for one of the microsatellites (FRPP91), one allele (allele number 13, absolute size $173 \mathrm{bp}$ ) displayed divergent frequencies in the Corsican and the Aquitaine provenances ( 0.680 and 0.004 , respectively). Furthermore, the differentiation between the two provenances $\left(F_{\mathrm{ST}}=0.184\right)$ was high and significantly different from 0 .

Ribeiro et al. [22] developed a statistical test on chloroplast microsatellites to determine the putative origin (French versus Northwest Iberic) of forest stands sampled in Aquitaine region of France. The same approach was used in the present study with the nuclear microsatellite data set in order to develop a test to distinguish Corsican from Aquitaine populations. For this purpose, the Devinas population, recently introduced in Aquitaine, was used as the population to be tested. The test performed with each microsatellite locus separately, and with all the loci combined together, was adapted to diploid data as follows (for details see Ribeiro et al. [22]):

(1) a null hypothesis was drawn: " $H_{0}$ : the tested sample (Devinas) belongs to the Aquitaine population" and the alternative hypothesis was " $H_{1}$ : the tested sample (Devinas) belongs to the Corsica population";

(2) a statistic was built with the allelic frequencies of each locus or all together: $S_{k}=\sum_{i=1}^{r} \sum_{j=1}^{n}\left(x_{i j}^{R}-x_{i j}^{k}\right)^{2}$;

(3) this formula was used to obtain the distribution of the null and the alternative hypotheses, where $r$ is the total number of studied loci $(r=1$ or $r=3), n$ is the total number of alleles at the $i$ th locus found in the Aquitaine and the Corsican groups of populations, $x_{i j}^{R}$ is the frequency of the $j$ th allele at the $i$ th locus in the reference population (chosen as the Aquitaine group of populations) and $x_{i j}^{k}$ is the frequency of the $j$ th allele at the $i$ th locus in a sample $k$ from the Aquitaine group of populations (to obtain $H_{0}$ ) or $x_{i j}^{k}$ is the frequency of the $j$ th allele at the $i$ th locus in a sample $k$ from the Corsican group of populations (to obtain $H_{1}$ ); the size of each sample $k$ that was used in bootstraps was 30;

(4) the distribution of $S_{k}$ for the null and alternative hypothesis was obtained by repeating 10000 times the calculation $(k=1$ to 10000$)$;

(5) the decision of either accepting or rejecting the null hypothesis was made by comparing the value of the statistics for the tested sample (Devinas), $S_{D}$, with the values of $S$ for $H_{0}$ and $H_{1}$.

\section{RESULTS}

\subsection{Population genetic diversity analysis at each locus}

At the population level, the three analysed loci showed heterogeneous levels of diversity and fixation index values. FRPP91 showed a high level of heterozygosity and allelic 
richness but a low mean level of fixation index (table II) whereas FRPP94 revealed a limited level of diversity and a higher fixation index than FRPP91 (table III). Finally, ITPH4516 showed a high level of heterozygosity and allelic richness but generally revealed a significant positive fixation index within populations (table IV).

\subsection{Principal Component Analysis grouping of populations}

Based on the PCA (figure 2) the P. pinaster populations were clustered into three main groups. One group (No. 1 or "west of France group") composed with populations from Aquitaine, West of France, Gard and Corbières, group 2 (or "south east of France group") composed with Corsican populations and four south east of France populations (Maures, Alpes Maritimes, Var and Esterel), and group 3 clustering populations from the Iberian Peninsula (Spain and Portugal) and Morocco. Clustering the Portuguese populations in group 3 was done for geographical reasons, for they could have been grouped in "west of France group", No. 1, instead.

The first component explained $34 \%$ of the total variance and the second component explained $12 \%$. In the first component the highest correlation was obtained with the frequency of the discriminant allele found between Corsican and Aquitaine populations, at the locus FRPP91 $(r=-0.900)$. The frequency of this allele was $0.015,0.579,0.035$, and 0.135 in group 1, 2, the Iberian and the Moroccan populations, respectively.

\subsection{Within and among geographical groups diversity analysis}

Based on the results obtained with the PCA and the geographical distribution of the populations, genetic analyses were undertaken for the three groups of populations. When $H_{\mathrm{E}}$ and $H_{0}$ were considered, the highest levels of diversity were found in group 3 (Moroccan and Iberian populations). In addition, levels of diversity tended to be higher in the "west of France group" than in the "south east of France group" (table V). However, these results were not significant. At the population level, $A_{P}$ was the higher in the populations from the "west of France group" and in the Iberian Peninsula. However, the number of rare alleles was higher in the "south east of France group", especially in Corsica, than in the other groups (data not shown).

The mean fixation index $\left(F_{\text {IS }}\right)$ was higher in the populations belonging to the group 2 than in the other groups (tables II-V). Finally, as indicated by the levels of $F_{\mathrm{ST}}$ in $t a-$ ble $V$, populations from the "south east of France group" were more differentiated among them (0.066) in comparison with the differentiation found among the populations from the "west of France group" (0.016) and among the group 3 populations $(0.030) . \rho_{\mathrm{ST}}$ values indicated similar tendencies (0.031 among the group 1 populations, 0.061 among the
Table II. FRPP91 genetic diversity statistics in each population of $P$. pinaster.

\begin{tabular}{|c|c|c|c|c|c|c|}
\hline Population Id & $H_{\mathrm{o}}$ & $\operatorname{Sd}\left(H_{\mathrm{O}}\right)$ & $H_{\mathrm{E}}$ & $\operatorname{Sd}\left(H_{\mathrm{E}}\right)$ & $F_{\text {IS }}$ & $A$ \\
\hline Aq1 & 0.933 & 0.045 & 0.819 & 0.024 & -0.162 & 12 \\
\hline $\mathrm{Aq} 2$ & 0.933 & 0.045 & 0.862 & 0.024 & -0.103 & 18 \\
\hline $\mathrm{Aq} 3$ & 0.897 & 0.057 & 0.806 & 0.029 & -0.134 & 12 \\
\hline $\mathrm{Aq} 4$ & 0.613 & 0.087 & 0.819 & 0.022 & 0.243 & 11 \\
\hline Aq5 & 0.821 & 0.072 & 0.815 & 0.023 & -0.026 & 11 \\
\hline Aq6 & 0.724 & 0.083 & 0.750 & 0.027 & 0.018 & 7 \\
\hline Aq7 & 0.750 & 0.077 & 0.813 & 0.019 & 0.065 & 11 \\
\hline Aq8 & 0.810 & 0.086 & 0.830 & 0.033 & 0.001 & 12 \\
\hline $\mathrm{Aq} 9$ & 0.793 & 0.075 & 0.795 & 0.024 & -0.014 & 9 \\
\hline Aq10 & 0.917 & 0.056 & 0.803 & 0.023 & -0.169 & 9 \\
\hline Aq11 & 0.767 & 0.077 & 0.814 & 0.019 & 0.043 & 10 \\
\hline Aq12 & 0.793 & 0.075 & 0.766 & 0.035 & -0.055 & 12 \\
\hline Aq13 & 0.750 & 0.082 & 0.856 & 0.022 & 0.110 & 13 \\
\hline $\mathrm{Co} 1$ & 0.417 & 0.101 & 0.431 & 0.091 & 0.014 & 12 \\
\hline $\mathrm{Co} 2$ & 0.400 & 0.098 & 0.442 & 0.087 & 0.077 & 9 \\
\hline $\mathrm{Co} 3$ & 0.227 & 0.089 & 0.426 & 0.092 & 0.459 & 7 \\
\hline $\mathrm{Co} 4$ & 0.333 & 0.096 & 0.454 & 0.087 & 0.254 & 8 \\
\hline Co5 & 0.375 & 0.099 & 0.595 & 0.072 & 0.361 & 7 \\
\hline Co6 & 0.409 & 0.105 & 0.480 & 0.086 & 0.132 & 7 \\
\hline $\mathrm{Co} 7$ & 0.435 & 0.103 & 0.504 & 0.089 & 0.120 & 10 \\
\hline $\mathrm{Co} 8$ & 0.696 & 0.096 & 0.612 & 0.071 & -0.166 & 8 \\
\hline $\mathrm{Co} 9$ & 0.783 & 0.086 & 0.713 & 0.063 & -0.125 & 9 \\
\hline Co10 & 0.280 & 0.090 & 0.442 & 0.087 & 0.359 & 9 \\
\hline Devinas & 0.644 & 0.071 & 0.655 & 0.050 & 0.005 & 10 \\
\hline Go1 & 0.900 & 0.055 & 0.833 & 0.024 & -0.100 & 12 \\
\hline Go2 & 0.933 & 0.045 & 0.825 & 0.023 & -0.153 & 10 \\
\hline Go3 & 0.733 & 0.081 & 0.781 & 0.029 & 0.046 & 13 \\
\hline Go4 & 0.750 & 0.082 & 0.879 & 0.020 & 0.134 & 16 \\
\hline Go5 & 0.769 & 0.083 & 0.813 & 0.034 & 0.036 & 11 \\
\hline Go6 & 0.821 & 0.072 & 0.791 & 0.030 & -0.057 & 10 \\
\hline Go7 & 0.731 & 0.087 & 0.835 & 0.029 & 0.110 & 13 \\
\hline Go8 & 0.654 & 0.093 & 0.834 & 0.033 & 0.204 & 16 \\
\hline Go9 & 0.571 & 0.094 & 0.872 & 0.020 & 0.337 & 15 \\
\hline Go10 & 0.885 & 0.063 & 0.836 & 0.023 & -0.080 & 11 \\
\hline $\mathrm{Se} 1$ & 0.600 & 0.098 & 0.698 & 0.058 & 0.125 & 11 \\
\hline $\mathrm{Se} 2$ & 0.840 & 0.073 & 0.804 & 0.033 & -0.067 & 11 \\
\hline $\mathrm{Se} 3$ & 0.875 & 0.068 & 0.807 & 0.037 & -0.109 & 13 \\
\hline $\mathrm{Se} 4$ & 0.864 & 0.073 & 0.738 & 0.042 & -0.203 & 9 \\
\hline Se5 & 0.739 & 0.092 & 0.824 & 0.035 & 0.085 & 13 \\
\hline Se6 & 0.870 & 0.070 & 0.883 & 0.023 & -0.007 & 15 \\
\hline Sp1 & 0.900 & 0.055 & 0.894 & 0.017 & -0.023 & 15 \\
\hline $\mathrm{Sp} 2$ & 0.767 & 0.077 & 0.923 & 0.010 & 0.158 & 19 \\
\hline Sp3 & 0.893 & 0.058 & 0.905 & 0.009 & -0.004 & 13 \\
\hline Sp4 & 0.933 & 0.045 & 0.902 & 0.013 & -0.053 & 16 \\
\hline Po1 & 1.000 & 0.000 & 0.864 & 0.028 & -0.196 & 12 \\
\hline Po2 & 0.842 & 0.084 & 0.852 & 0.020 & -0.015 & 9 \\
\hline Mor & 0.958 & 0.041 & 0.875 & 0.019 & -0.121 & 11 \\
\hline Mean & 0.730 & - & 0.757 & - & 0.029 & 11.43 \\
\hline
\end{tabular}

See references of parameters in the text. 
Table III. FRPP94 genetic diversity statistics in each population of $P$. pinaster.

\begin{tabular}{|c|c|c|c|c|c|c|}
\hline Population Id & $H_{\mathrm{o}}$ & $\operatorname{Sd}\left(H_{\mathrm{O}}\right)$ & $H_{\mathrm{E}}$ & $\operatorname{Sd}\left(H_{\mathrm{E}}\right)$ & $F_{\text {IS }}$ & $A$ \\
\hline Aq1 & 0.621 & 0.090 & 0.611 & 0.051 & -0.034 & 7 \\
\hline $\mathrm{Aq} 2$ & 0.462 & 0.098 & 0.628 & 0.054 & 0.254 & 6 \\
\hline $\mathrm{Aq} 3$ & 0.556 & 0.096 & 0.634 & 0.054 & 0.109 & 7 \\
\hline $\mathrm{Aq} 4$ & 0.310 & 0.086 & 0.618 & 0.035 & 0.493 & 6 \\
\hline Aq5 & 0.556 & 0.096 & 0.643 & 0.050 & 0.122 & 7 \\
\hline Aq6 & 0.429 & 0.094 & 0.648 & 0.046 & 0.331 & 7 \\
\hline Aq7 & 0.536 & 0.094 & 0.603 & 0.046 & 0.097 & 5 \\
\hline Aq8 & 0.579 & 0.113 & 0.643 & 0.055 & 0.077 & 7 \\
\hline Aq9 & 0.483 & 0.093 & 0.600 & 0.037 & 0.185 & 6 \\
\hline Aq10 & 0.688 & 0.116 & 0.582 & 0.047 & -0.226 & 5 \\
\hline Aq11 & 0.731 & 0.087 & 0.700 & 0.038 & -0.066 & 8 \\
\hline Aq12 & 0.679 & 0.088 & 0.624 & 0.037 & -0.109 & 7 \\
\hline Aq13 & 0.407 & 0.095 & 0.607 & 0.059 & 0.320 & 8 \\
\hline Co1 & 0.864 & 0.073 & 0.788 & 0.021 & -0.124 & 6 \\
\hline $\mathrm{Co} 2$ & 0.667 & 0.096 & 0.745 & 0.026 & 0.088 & 6 \\
\hline $\mathrm{Co} 3$ & 0.591 & 0.105 & 0.771 & 0.040 & 0.220 & 9 \\
\hline $\mathrm{Co} 4$ & 0.500 & 0.102 & 0.839 & 0.024 & 0.396 & 12 \\
\hline $\operatorname{Co} 5$ & 0.625 & 0.099 & 0.731 & 0.033 & 0.129 & 6 \\
\hline Co6 & 0.444 & 0.117 & 0.741 & 0.037 & 0.390 & 7 \\
\hline $\mathrm{Co} 7$ & 0.773 & 0.089 & 0.830 & 0.020 & 0.048 & 8 \\
\hline $\mathrm{Co} 8$ & 0.682 & 0.099 & 0.704 & 0.034 & 0.009 & 6 \\
\hline $\mathrm{Co} 9$ & 0.875 & 0.068 & 0.729 & 0.033 & -0.231 & 7 \\
\hline Co10 & 0.545 & 0.106 & 0.646 & 0.074 & 0.139 & 9 \\
\hline Devinas & 0.689 & 0.069 & 0.774 & 0.026 & 0.101 & 11 \\
\hline Go1 & 0.600 & 0.089 & 0.553 & 0.033 & -0.105 & 4 \\
\hline Go2 & 0.633 & 0.088 & 0.629 & 0.037 & -0.024 & 6 \\
\hline Go3 & 0.700 & 0.084 & 0.600 & 0.044 & -0.190 & 7 \\
\hline Go4 & 0.393 & 0.092 & 0.543 & 0.041 & 0.267 & 4 \\
\hline Go5 & 0.586 & 0.091 & 0.579 & 0.033 & -0.030 & 6 \\
\hline Go6 & 0.600 & 0.089 & 0.690 & 0.035 & 0.118 & 7 \\
\hline Go7 & 0.778 & 0.080 & 0.673 & 0.048 & -0.181 & 10 \\
\hline Go8 & 0.448 & 0.092 & 0.660 & 0.047 & 0.313 & 8 \\
\hline Go9 & 0.714 & 0.085 & 0.691 & 0.037 & -0.054 & 8 \\
\hline Go10 & 0.667 & 0.091 & 0.645 & 0.039 & -0.054 & 7 \\
\hline Se1 & 0.826 & 0.079 & 0.847 & 0.017 & 0.003 & 9 \\
\hline $\mathrm{Se} 2$ & 0.913 & 0.059 & 0.810 & 0.029 & -0.156 & 10 \\
\hline $\mathrm{Se} 3$ & 0.714 & 0.099 & 0.840 & 0.024 & 0.132 & 10 \\
\hline $\mathrm{Se} 4$ & 0.680 & 0.093 & 0.863 & 0.019 & 0.200 & 13 \\
\hline $\operatorname{Se} 5$ & 0.600 & 0.110 & 0.670 & 0.051 & 0.084 & 7 \\
\hline Se6 & 0.550 & 0.111 & 0.580 & 0.072 & 0.029 & 6 \\
\hline Sp1 & 0.667 & 0.086 & 0.761 & 0.029 & 0.111 & 7 \\
\hline $\mathrm{Sp} 2$ & 0.667 & 0.086 & 0.773 & 0.025 & 0.125 & 9 \\
\hline $\mathrm{Sp} 3$ & 0.741 & 0.084 & 0.781 & 0.038 & 0.035 & 8 \\
\hline Sp4 & 0.667 & 0.086 & 0.767 & 0.033 & 0.118 & 7 \\
\hline Po1 & 0.667 & 0.111 & 0.690 & 0.049 & 0.007 & 6 \\
\hline Po2 & 0.526 & 0.115 & 0.611 & 0.042 & 0.118 & 4 \\
\hline Mor & 0.667 & 0.136 & 0.806 & 0.042 & 0.144 & 8 \\
\hline Mean & 0.623 & - & 0.691 & - & 0.079 & 7.32 \\
\hline
\end{tabular}

See references of parameters in the text.
Table IV. ITPH4516 genetic diversity statistics in each population of $P$. pinaster.

\begin{tabular}{|c|c|c|c|c|c|c|}
\hline Population Id & $H_{\mathrm{o}}$ & $\operatorname{Sd}\left(H_{\mathrm{O}}\right)$ & $H_{\mathrm{E}}$ & $\operatorname{Sd}\left(H_{\mathrm{E}}\right)$ & $F_{\text {IS }}$ & $A$ \\
\hline Aq1 & 0.714 & 0.085 & 0.848 & 0.025 & 0.144 & 11 \\
\hline Aq2 & 0.724 & 0.083 & 0.835 & 0.028 & 0.119 & 13 \\
\hline Aq3 & 0.759 & 0.079 & 0.812 & 0.025 & 0.051 & 11 \\
\hline Aq4 & 0.567 & 0.090 & 0.812 & 0.021 & 0.294 & 9 \\
\hline Aq5 & 0.893 & 0.058 & 0.830 & 0.019 & -0.097 & 9 \\
\hline Aq6 & 0.767 & 0.077 & 0.834 & 0.026 & 0.067 & 13 \\
\hline Aq7 & 0.800 & 0.073 & 0.840 & 0.023 & 0.032 & 11 \\
\hline Aq8 & 0.714 & 0.099 & 0.921 & 0.010 & 0.210 & 16 \\
\hline Aq9 & 0.846 & 0.071 & 0.898 & 0.018 & 0.040 & 17 \\
\hline Aq10 & 0.773 & 0.089 & 0.888 & 0.018 & 0.113 & 14 \\
\hline Aq11 & 0.640 & 0.096 & 0.799 & 0.035 & 0.186 & 11 \\
\hline Aq12 & 0.679 & 0.088 & 0.895 & 0.015 & 0.232 & 14 \\
\hline Aq13 & 0.759 & 0.079 & 0.865 & 0.025 & 0.110 & 16 \\
\hline Co1 & 0.696 & 0.096 & 0.817 & 0.019 & 0.132 & 7 \\
\hline $\mathrm{Co} 2$ & 0.926 & 0.050 & 0.702 & 0.046 & -0.351 & 7 \\
\hline Co3 & 0.522 & 0.104 & 0.601 & 0.067 & 0.115 & 6 \\
\hline Co4 & 0.652 & 0.099 & 0.850 & 0.020 & 0.219 & 11 \\
\hline Co5 & 0.417 & 0.101 & 0.800 & 0.040 & 0.474 & 10 \\
\hline Co6 & 0.524 & 0.109 & 0.764 & 0.034 & 0.303 & 9 \\
\hline $\mathrm{Co} 7$ & 0.667 & 0.136 & 0.705 & 0.084 & 0.015 & 8 \\
\hline $\operatorname{Co} 8$ & 0.435 & 0.103 & 0.558 & 0.074 & 0.207 & 8 \\
\hline Co9 & 0.556 & 0.117 & 0.810 & 0.038 & 0.301 & 10 \\
\hline Co10 & 0.619 & 0.106 & 0.821 & 0.027 & 0.232 & 11 \\
\hline Devinas & 0.622 & 0.072 & 0.747 & 0.037 & 0.159 & 12 \\
\hline Go1 & 0.767 & 0.077 & 0.866 & 0.017 & 0.101 & 13 \\
\hline Go2 & 0.833 & 0.068 & 0.853 & 0.020 & 0.007 & 11 \\
\hline Go3 & 0.733 & 0.081 & 0.762 & 0.042 & 0.022 & 12 \\
\hline Go4 & 0.714 & 0.085 & 0.881 & 0.023 & 0.177 & 17 \\
\hline Go5 & 0.786 & 0.078 & 0.834 & 0.035 & 0.041 & 14 \\
\hline Go6 & 0.655 & 0.088 & 0.797 & 0.035 & 0.166 & 15 \\
\hline Go7 & 0.704 & 0.088 & 0.907 & 0.017 & 0.213 & 18 \\
\hline Go8 & 0.630 & 0.093 & 0.871 & 0.020 & 0.267 & 13 \\
\hline Go9 & 0.552 & 0.092 & 0.813 & 0.033 & 0.314 & 13 \\
\hline Go10 & 0.655 & 0.088 & 0.832 & 0.029 & 0.201 & 15 \\
\hline $\mathrm{Se} 1$ & 0.571 & 0.108 & 0.800 & 0.045 & 0.274 & 12 \\
\hline $\mathrm{Se} 2$ & 0.348 & 0.099 & 0.807 & 0.025 & 0.565 & 8 \\
\hline $\mathrm{Se} 3$ & 0.727 & 0.095 & 0.833 & 0.039 & 0.109 & 15 \\
\hline $\mathrm{Se} 4$ & 0.318 & 0.099 & 0.832 & 0.029 & 0.614 & 11 \\
\hline Se5 & 0.636 & 0.103 & 0.889 & 0.016 & 0.273 & 15 \\
\hline Se6 & 0.667 & 0.103 & 0.907 & 0.017 & 0.252 & 17 \\
\hline Sp1 & 0.867 & 0.062 & 0.873 & 0.014 & -0.010 & 12 \\
\hline $\mathrm{Sp} 2$ & 0.767 & 0.077 & 0.844 & 0.026 & 0.078 & 14 \\
\hline Sp3 & 0.889 & 0.060 & 0.840 & 0.025 & -0.080 & 11 \\
\hline Sp4 & 0.900 & 0.055 & 0.870 & 0.021 & -0.053 & 13 \\
\hline Po1 & 0.727 & 0.134 & 0.818 & 0.032 & 0.074 & 7 \\
\hline Po2 & 0.625 & 0.171 & 0.664 & 0.083 & 0.000 & 4 \\
\hline Mor & 1.000 & 0.000 & 0.770 & 0.066 & -0.413 & 8 \\
\hline Mean & 0.688 & - & 0.817 & - & 0.138 & 11.74 \\
\hline
\end{tabular}

See references of parameters in the text. 


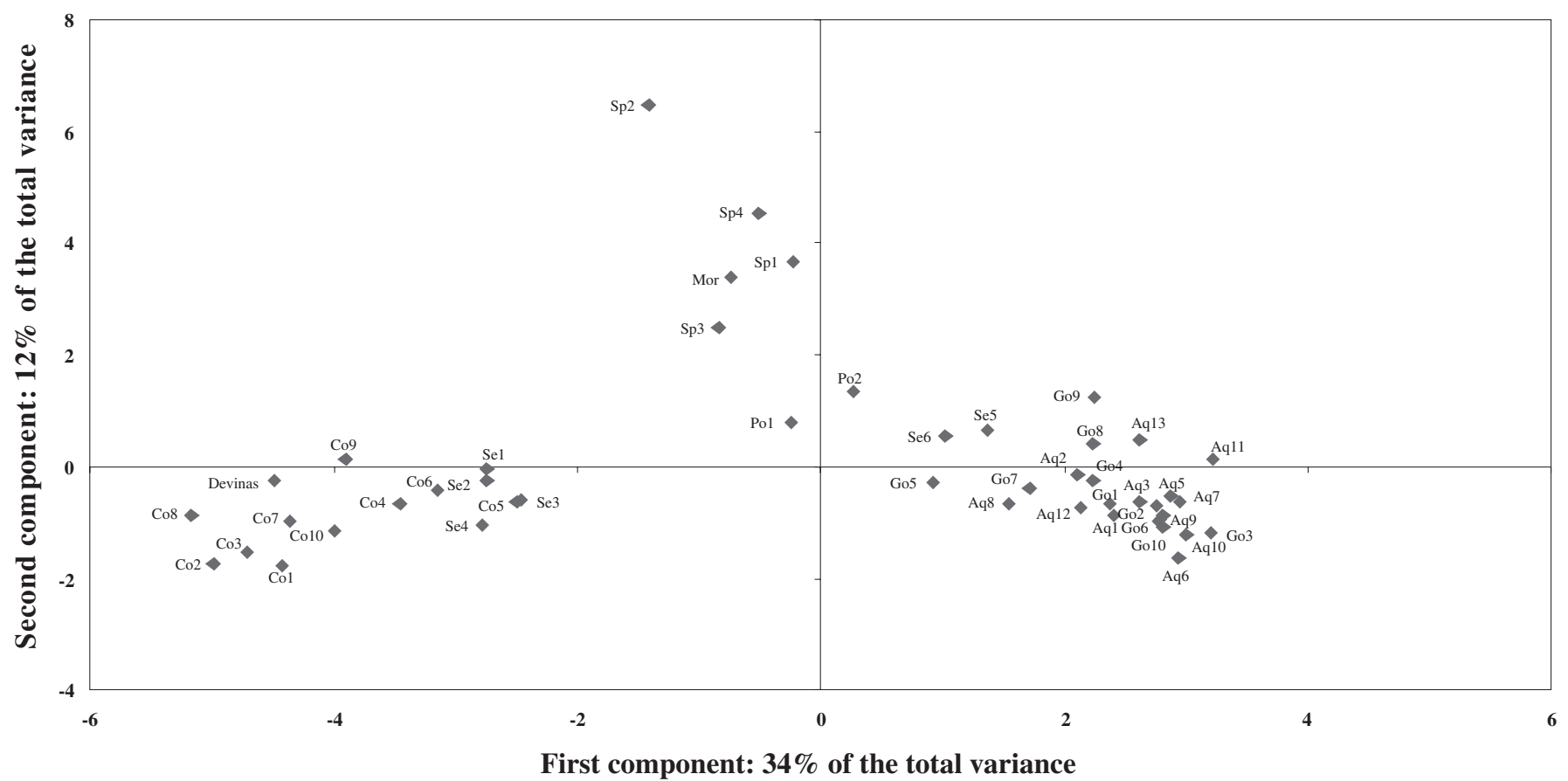

Figure 2. Principal component analysis on the 47 populations of $P$. pinaster.

Table V. Genetic diversity statistics for microsatellite loci in geographical groups of $P$. pinaster.

\begin{tabular}{lcccccccccc}
\hline Geographical group & $A^{\mathrm{P}}$ & $\mathrm{Sd}\left(A^{\mathrm{P}}\right)$ & $H_{\mathrm{O}}$ & $\mathrm{Sd}\left(H_{\mathrm{O}}\right)$ & $H_{\mathrm{E}}^{\mathrm{P}}$ & $\mathrm{Sd}\left(H_{\mathrm{E}}^{\mathrm{P}}\right)$ & $F_{\mathrm{IS}}^{\mathrm{P}}$ & $\mathrm{Sd}\left(F_{\mathrm{IS}}^{\mathrm{P}}\right)$ & $F_{\text {ST }}$ & $\rho_{\mathrm{ST}}$ \\
\hline West (group 1) & 10.75 & 1.41 & 0.695 & 0.068 & 0.766 & 0.021 & 0.075 & 0.104 & 0.016 & 0.031 \\
South east (group 2) & 9.20 & 1.67 & 0.608 & 0.107 & 0.710 & 0.074 & 0.132 & 0.125 & 0.066 & 0.061 \\
I. Peninsula (group 3) & 10.33 & 2.94 & 0.792 & 0.068 & 0.826 & 0.055 & 0.022 & 0.068 & 0.033 & 0.010 \\
\hline
\end{tabular}

See references of parameters in the text.

group 2 populations and 0.010 among the group 3 populations).

\subsection{Genetic differentiation between provenance groups}

The highest among provenances differentiation was found between group 1 and 2, as indicated by $F_{\mathrm{ST}}$ and $\rho_{\mathrm{ST}}$ values: 0.071 and 0.106 , respectively (table VI). Group 2 was significantly differentiated from the group 3 of populations $\left(F_{\mathrm{ST}}=0.044\right.$ and $\left.\rho_{\mathrm{ST}}=0.081\right)$, whereas the differentiation between the west of France group and the group 3 of populations $\left(F_{\mathrm{ST}}=0.018\right.$ and $\left.\rho_{\mathrm{ST}}=0.017\right)$ had a much lower value, while significantly different from 0 .

Differentiation was highly significant for all pairs of groups (all cases $P<0.0000$ ).

\subsection{Use of nuclear microsatellites to distinguish Corsican from Aquitaine populations}

The frequency of the discriminant allele at the locus FRPP91 in the Devinas population was 0.550 , very close from the frequency found in the Corsican populations (0.660). This indicated that Devinas could be classified as a Corsican population. Moreover, the differentiation found between Devinas and the Corsican populations was not significantly different from 0 .

Table VI. Genetic differentiation $\left(F_{\mathrm{ST}}\right.$ and $\left.\rho_{\mathrm{ST}}\right)$ between geographical groups of $P$. pinaster.

\begin{tabular}{lcc}
\hline & $\begin{array}{c}\text { West } \\
\text { (group 1) }\end{array}$ & $\begin{array}{c}\text { South east } \\
\text { (group 2) }\end{array}$ \\
\hline $\begin{array}{l}\text { South east } \\
\text { (group 2) }\end{array}$ & $F_{\mathrm{ST}}=0.071$ & - \\
Iberian Peninsula & $\rho_{\mathrm{ST}}=0.106$ & \\
(group 3) & $F_{\mathrm{ST}}=0.018$ & $F_{\mathrm{ST}}=0.044$ \\
\hline
\end{tabular}



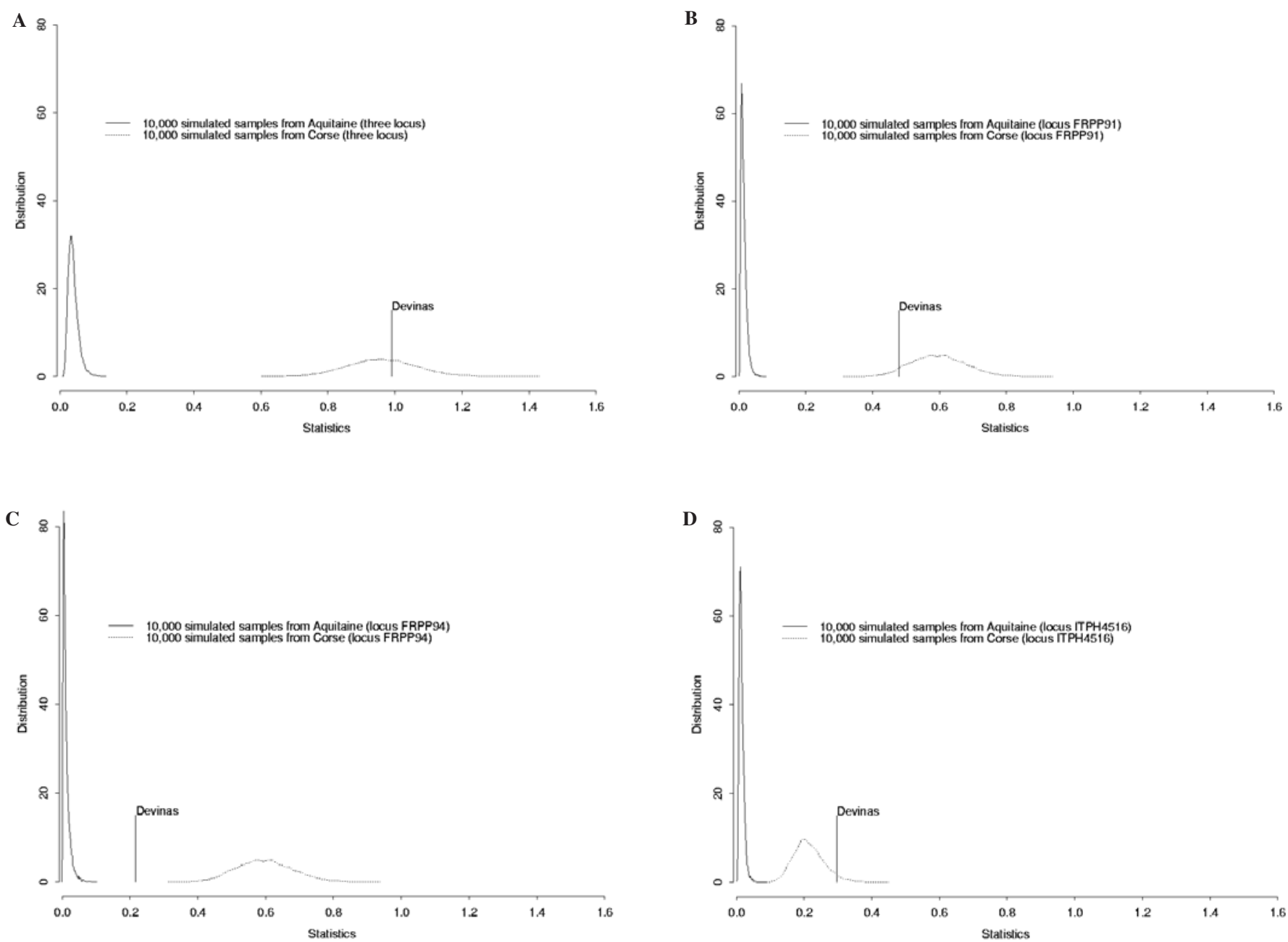

Figure 3. A. $S$ distribution at the three locus for the Corsican and the Aquitaine provenances, and location of the statistics $S_{D}$ of Devinas population. B. $S$ distribution at the locus FRPP91 for the Corsican and the Aquitaine provenances, and location of the statistics $S_{D}$ of the Devinas population. C. $S$ distribution at the locus FRPP94 for the Corsican and the Aquitaine provenances, and location of the statistics $S_{D}$ of the Devinas population. D. $S$ distribution at the locus ITPH4516 for the Corsican and the Aquitaine provenances, and location of the statistics $S_{D}$ of the Devinas population.

When the statistics test was constructed with the three microsatellites, the $S$ statistics of the Devinas population was found to be 0.99 . The comparison of this value with the $S$ distributions of Corsican and Aquitaine groups of populations revealed that Devinas was originated from Corsica (figure $3 A$ ). The use of only one microsatellite gave a similar result, both for FRPP91 (figure 3B) and ITPH4516 (figure 3D). However, in the case of FRPP94, despite the fact that the two $S$ distributions of Corsican and Aquitaine groups of populations were distinct, the test did not allow to attribute the Devinas population to Corsica (figure 3C). In conclusion, the information given by locus FRPP91 or by locus ITPH4516 was sufficient to clarify the origin of the Devinas population.

\section{DISCUSSION}

\subsection{Geographical genetic differentiation of $P$. pinaster}

Based on terpene markers, palynological and paleoclimatological records, Baradat and Marpeau-Bezard [4] discriminated three major groups of $P$. pinaster: the "Atlantic group", comprising populations from southwestern France, Portugal and Galicia in Spain; the "Mediterranean group", extending from central Spain to the Ligurian coast in Italy; and finally the "North African" group that includes stands from Morocco, Algeria and Tunisia. In another study, Bahrman et al. [3] included eastern Spain in the "Atlantic group". 
In our study, three major groups of populations were discriminated based on the PCA: group 1 comprising populations from the west of France, (including Gard and Corbières), group 2 comprising Corsica and populations from the south east of France (Maures, Alpes Maritimes, Var and Esterel), and group 3 comprising populations from Portugal, Spain and Morocco. Group 1 was highly differentiated from group 2, but group 1 was only slightly differentiated from group 3. These results suggest that the Spanish populations could be included in the "Atlantic group" rather than the "Mediterranean group". This conclusion was also supported by a wide-range study using mitochondrial data (Burban, personal communication). However, it is important to stress that the populations from Portugal were closer to the western French populations than to the Spanish populations used in the present study. Previous studies with allozymes did not allow differentiation between Portuguese and Spanish origins (Salvador et al. [24]). The use of nuclear SSRs could be a promising tool to discriminate between seedlots from Portuguese provenances and Mediterranean provenances from central Spain.

An unexpected result was that the Moroccan population was not differentiated from the "Atlantic group". This population might have been originated with seed coming from the "Atlantic group", as confirmed by a study made with cpSSR (Vendramin, personal communication). However, this clustering of the Moroccan provenance should be cheked by using a broader number of populations from this region. Moreover, when the FRPP91 locus discriminant allele was considered, its frequency in the Morocco population (0.135) was intermediate between those found in the western populations (about 0 ) and in the eastern populations (0.579).

A general restriction of our study is the unequal number of populations that were sampled through the natural range of $P$. pinaster. However, based on the mitochondrial DNA study of Burban (unpublished results), we have a representative sampling of the western (Landes, Portugal and Spain) and eastern phylogenies. Moreover, the populations from Italy are also 'represented' as they belong to the eastern phylogeny. The selection of a low number of Iberian populations is based on previous studies. In fact, the four Spanish populations are typical locations of the four main groups of populations detected in Spain with allozymes by Salvador et al. [24] and González-Martínez et al. [11]: North West, East and South East (which is divided in two subgroups, both represented in the present study).

\subsection{How far microsatellites can be used to define genetic resources conservation strategies in $P$. pinaster?}

Microsatellite data obtained for $P$. pinaster showed contrasting genetic characteristics among geographical groups. The eastern populations (group 2) displayed a lower level of heterozygosity and a higher fixation index than the western populations (groups 1 and 3), indicating a deficiency of heterozygotes in the populations. This is especially true for the locus FRPP91 (table II). Moreover, the differentiation among populations was much higher in the eastern populations $(0.066)$ than in the western populations $(0.016$ in the west of France and 0.033 in the Iberian populations).

Conservation strategies should reflect those differences found within each group of populations. In the eastern group, microsatellite data could be useful to identify populations with private alleles in order to hold diversity reservoirs. The among population differentiation in the western groups was low within each geographical group; thus, the choice of populations should follow other criterias, by reflecting different types of ecological conditions for example. Moreover, the Iberian Peninsula populations exhibited the highest values of genetic diversity in the western group range of the species, and one population (Cómpeta) was highly differentiated from the others (figure 2). Therefore, this population could be considered in conservation programmes.

Nevertheless, the microsatellite data presented here are not sufficient to define genetic resource conservation strategies for $P$. pinaster. First, the number of markers that we considered is limited. Seventy-six SSR primer pairs from four Pinus species were tested to amplify microsatellites in $P$. pinaster (see details in Mariette et al. [17]). Twenty-six primer pairs were taken from a microsatellite library for $P$. pinaster and the other primer pairs were obtained from other species of the same genus ( $P$. radiata, $P$. strobus and $P$. halepensis). Only three out of the 76 SSR primer pairs amplified at a single polymorphic locus in $P$. pinaster. It is unlikely that a high number of SSR markers in this species will be found in the very short term. As a consequence, at the range scale of $P$. pinaster, all the available information from other neutral markers (isozymes, chloroplast microsatellites, AFLPs) should be considered to detect populations with higher levels of diversity or population specific alleles.

Second, the $F_{\text {IS }}$ estimates are large enough to suggest not only some inbreeding (particularly in Corsican populations) but also the existence of null alleles, especially for FRPP94 and ITPH4516 locus. The three $P$. pinaster loci were positioned on $P$. pinaster genetic maps and no null allele was detected. However, null alleles seem to be actually quite frequent in conifer species. This has already been reported in a study on $P$. radiata (Fisher et al. [10]), which pointed out the high frequency of null alleles in microsatellites of this species. It seems also to be the case in other species such as Picea abies (Scotti, personal communication). The use of microsatellites may therefore lead to underestimation of heterozygosity and allelic richness in conifer species.

Finally, phenotypic information given by field trials should be considered, for the stands to be preserved have to be chosen integrating both molecular and quantitative data. For example, some discriminant canonical analysis using allozymes and three quantitative traits (survival, height and 
stem form) was performed and some correlation between quantitative traits and molecular markers in maritime pine was found (Gonzaléz-Martínez, unpublished results). A slight concordance of morphological and allozymic variation has also been reported for other forest species with wide ranges (e.g. Pseudotsuga menziesii [8]; Picea abies [16]; Alnus rubra [12]).

\subsection{A tool for origin identification (Corsica $\times$ Aquitaine hybrid certification)}

A breeding programme for $P$. pinaster was initiated in the sixties in France, mainly based on the genetic variability available in Aquitaine. The Corsican populations were recently integrated to the programme, because they exhibit a better stem form, in general, whereas the Aquitaine populations are more cold resistant and vigorous. Thus, Aquitaine $x$ Corsica hybrids will be produced within the frame of the programme. Moreover, the future development of hybrid varieties has been raised as a potential plan by the French state agency (National Forest Office: ONF).

It was possible to discriminate the distribution curves of the Aquitaine and the Corsican populations by using the three microsatellites or each microsatellite separately (figures $3 \mathrm{~A}$ to $3 D$ ). The Devinas population was tested and was found to be of Corsican origin by using the three microsatellites pooled or by using either the FRPP91 or the ITPH4516.

A more economic efficient method could be achieved by using only one microsatellite. The FRPP91 locus gave the highest differentiation between the two provenances and when the distribution curves were compared, this locus showed very distinct distribution for the two provenances. Therefore, this locus could be used solely in the identification test.

The result obtained in the foregoing paper could be applied for certification of Corsica $\times$ Aquitaine hybrid varieties. The $S$ statistic distribution of a hybrid population could be established by using a large number of individuals originating from crossings between Aquitaine and Corsican individuals. This distribution should be completely distinct from the Aquitaine and the Corsica distribution curves, especially when the three microsatellites are pooled, or when locus FRPP91 or FRPP94 are used, since the Corsica and the Aquitaine curves did not overlap in those cases. A statistic could be computed from a $\lambda$ sample (a seed lot which origin ought to be controlled), and further compared with the three distributions (Aquitaine, Corsica and hybrid). Moreover, the marker and the statistical approach are useful for $P$. pinaster provenance identification, but can also be applied to other forest tree identification problems, provided that the microsatellite information is available and that the distribution curves will not overlap.

Acknowledgements: This work was supported by grants from France (Ministère de l'Agriculture et de la Pêche-DERF No. 61.21.04/98 and DERF No. 61.45.0401), Spain (Cooperation project DGCN-INIA CC00-0035), and the European Union (INCO-DC 18CT97-200). Santiago C. González-Martínez was supported by a FPU scholarship from MECD (Ministerio de Educación, Cultura y Deporte, Spain). The authors are very thankful to two anonymous reviewers for their helpful comments on a previous version of the manuscript. We also thank Ivan Scotti for thoughtful comments concerning null alleles in conifer species.

\section{REFERENCES}

[1] Alía R., Gil L., Pardos J.A., Performance of 43 Pinus pinaster provenances on 5 locations in Central Spain, Silvae Genet. 44 (1995) 75-81.

[2] Alía R., Moro J., Denis J.B., Performance of Pinus pinaster provenances in Spain: interpretation of the genotype by environment interaction, Can. J. For. Res. 27 (1997) 1548-1559.

[3] Bahrman N., Zivy M., Baradat P., Damerval C., Organization of the variability of abundant proteins in seven geographical origins of maritime pine (Pinus pinaster Ait.), Theor. Appl. Genet. 88 (1994) 407-411.

[4] Baradat P., Marpeau-Bezard A., Le pin maritime, Pinus pinaster Ait., biologie et génétique des terpènes pour la connaissance et l'amélioration de l'espèce, Ph.D. Thesis, University of Bordeaux I, 1988.

[5] Boisseaux T., Influence de l'origine génétique (landaise ou ibérique) des peuplements de Pin maritime sur les dégâts causés par le froid de janvier 1985 au massif forestier aquitain. Mise au point d'un test variétal précoce utilisable pour le contrôle de lots de graines, Mémoire de l'ENITEF Thesis, University of Bordeaux, 1986.

[6] Brown A.H.D., Weir B.S., Measuring genetic variability in plant populations, in: Tanksley S.D., Orton T.J. (Eds.), Isozymes in plant genetics and breeding Part A, Elsevier Science Publishers B.V., Amsterdam, 1983, pp. 219-239.

[7] Doyle J.J., Doyle J.L., Isolation of plant DNA from fresh tissue, Focus 12 (1990) 13-15.

[8] El-Kassaby Y.A., Associations between allozyme genotypes and quantitative traits in Douglas-fir (Pseudotsuga menziesii (Mirb.) Franco), Genetics 101 (1982) 103-115.

[9] Farjon A., Pines: drawings and descriptions of the genus Pinus, Brill E.J. (Ed.), Leiden, 1984.

[10] Fisher P.J., Richardson T.E., Gardner R.C., Characteristics of singleand multi-copy microsatellites from Pinus radiata, Theor. Appl. Genet. 96 (1998) 969-979.

[11] González-Martínez S.C., Salvador L., Agúndez D., Alía R., Gil L., Geographical variation of gene diversity of Pinus pinaster Ait. in the Iberian Peninsula, in: Müller-Starck G., Schubert R. (Eds.), Genetic response of forest systems to changing environmental conditions, Kluwer Academic Press, Dordrecht, 2001, pp. 161-171.

[12] Hamman A., El-Kassaby Y.A., Koshy M.P., Namkoong G., Multivariate analysis of allozymic and quantitative trait variation in Alnus rubra: geographic patterns and evolutionary implications, Can. J. For. Res. 28 (1998) 1557-1565.

[13] Harfouche A., Kremer A., Provenance hybridization in a diallel mating scheme of maritime pine (Pinus pinaster), Can. J. For. Res. 30 (2000) 1-9.

[14] Jactel H., Ménassieu P., Burban C., Découverte en corse de Matsucoccus feytaudi Duc. (Homoptera: Margarodidae), cochenille du Pin maritime, Ann. Sci. For. 53 (1996) 145-152.

[15] Jactel H., Ménassieu P., Ceria A., Burban C., Regad J., Normand S., Carcreff E., Une pullulation de la cochenille Matsucoccus feytaudi provoque un début de dépérissement du Pin maritime en Corse, Rev. For. Fr. 50 (1998) 33-45.

[16] Lagerkrantz U., Ryman N., Genetic structure of Norway Spruce (Picea abies): concordance of morphological and allozymic variation, Evolution 44 (1990) 38-53.

[17] Mariette S., Chagné D., Decroocq S., Vendramin G.G., Lalanne C., Madur D., Plomion C., Microsatellite markers for Pinus pinaster Ait., Ann. For. Sci. 58 (2001) 203-206. 
[18] Mariette S., Chagné D., Lézier C., Pastuszka P., Raffin A., Plomion C., Kremer A., Genetic diversity within and among Pinus pinaster populations: comparison between AFLP and microsatellite markers, Heredity 86 (2001b) 469-479.

[19] Petit R.J., Bahrman N., Baradat P., Comparison of genetic differentiation in maritime pine (Pinus pinaster Ait.) estimated using isozyme, total protein and terpenic loci, Heredity 75 (1995) 382-389.

[20] Raymond M., Rousset F., An exact test for population differentiation, Evolution 49 (1995) 1280-1283.

[21] Ribeiro M.M., Plomion C., Petit R.J., Vendramin G.G., Szmidt A.E., Variation in chloroplast single-sequence repeats in Portuguese maritime pine (Pinus pinaster Ait.), Theor. Appl. Genet. 102 (2001) 97-103.

[22] Ribeiro M.M., LeProvost G., Gerber S., Vendramin G.G., Anzidei M., Decroocq S., Marpeau A., Mariette S., Plomion C., Origin identification of maritime pine stands in France using chloroplast single-sequence repeats, Ann. For. Sci. 59 (2002) 53-62.

[23] Rousset F., Equilibrium values of measure of population subdivision for stepwise mutation processes, Genetics 142 (1996) 1357-1362.

[24] Salvador L., Alía R., Agúndez D., Gil L., Genetic variation and migration pathways of maritime pine (Pinus pinaster Ait.) in the Iberian peninsula, Theor. Appl. Genet. 100 (2000) 89-95.

[25] Vendramin G.G., Anzidei M., Madaghiele A., Bucci G., Distribution of genetic diversity in Pinus pinaster Ait. as revealed by chloroplast microsatellites, Theor. Appl. Genet. 97 (1998) 456-463.

[26] Weir B.S., Cockerham C.C., Estimating $F$-statistics for the analysis of population structure, Evolution 38 (1984) 1358-1370.

To access this journal online: www.edpsciences.org 